\title{
Fluvial biofilm responses to joint changes in nutrients, temperature, turbidity and water velocity: an ex situ experiment
}

\section{Joaquín Cochero* and Nora Gómez}

Instituto de Limnología “Dr. Raúl A. Ringuelet”, CONICET - UNLP, Facultad de Ciencias Naturales y Museo, Universidad Nacional de La Plata, Avenida 122 y 60, La Plata, Buenos Aires, Argentina.*Email: jcochero@ilpla.edu.ar.

\begin{abstract}
The aim of this study was to explore the responses of the epipelic biofilm of a Pampean stream with little impact from human activity to two environmental conditions, with joint modifications in nutrients, temperature, water velocity and turbidity. The experiment was conducted using artificial channels and lasted five weeks. The biological variables measured included chlorophyll- $a$ content, bacterial biomass, ash-free dry weight, total carbohydrate concentration, total respiratory activity, and biofilm composition. Results show that the species' composition of the biofilm was affected, although no other structural or metabolic variables measured were. These results highlight the importance of including structural parameters to measure rapid changes in water quality, even when analyzing the effects of co-occurring variables.
\end{abstract}

Keywords: Epipelic biofilms; Water quality; Artificial channels; Temperature; Nutrients.
Received

May 10, 2016

Accepted

May 30, 2016

Released

June 30, 2016

Open Acess

Full Text Article

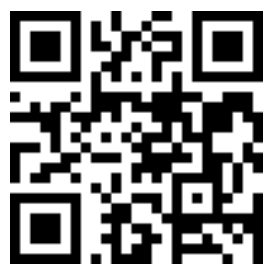

ORCID

(ㄱ) 0000-0003-3957-6819

Joaquín Cochero

(P) 0000-0003-0698-4007

Nora Gómez

\section{Introduction}

The land use change to produce goods and services represents one of the most important human alterations, affecting the structure and functioning of aquatic ecosystems in general. The loss of habitats, water extraction, pollution, resource overuse and the introduction of non native species have influences negatively in freshwater ecosystems. As a consequence to these pressures, the freshwater ecosystems are among the most vulnerable in the world (Revenga et al., 2005). Particularly in lotic fluvial systems, their sensitivity to human impact is magnified by their lineal and unidirectional nature; almost any activity conducted in the basin has the potential to influence the characteristics downstream up to a great extent (Malmqvist and Rundle, 2002).

In the Pampean plains, for example, are greatly influenced by human activity. The southernmost sector of these plains in 
Argentina has over 21 million inhabitants (INDEC, 2010) that conduct an intense agricultural and industrial activity, favouring the input of contaminants to the water bodies. On the other hand, the climatic models for the region also predict higher rainfalls (Hulme and Sheard, 1999), which can increase erosion and generate flooding, increasing the transport of sediments, nutrients, and contaminants into the water (Davies-Colley et al., 1992; Davies-Colley and Smith, 2001). Although the lotic systems from the Pampean plains have naturally high concentrations of nutrients when compared to other lotic systems in the world (Meybeck, 1982; 1987; Giorgi et al., 2005; Feijó and Lombardo, 2007), these modifications in land use, intensified by the effect of changes in climatic patterns, have repercussions on their water quality, altering their physical, chemical and hydrologic properties (Rodrigues Capitulo et al., 2010). For instance, an experimental addition of nutrients in a Pampean stream evidenced responses of the biotic communities different to those observed in water bodies from other biomes (Artigas et al., 2013).

Among the diverse communities that inhabit the streams, biofilms composed of algae, bacteria, fungi and protozoa, all embedded in an extracellular matrix (Lock et al., 1984) represent a pertinent bioindicator of environmental perturbations within the aquatic ecosystem (Bonnineau et al., 2010; Romaní et al., 2016). This community is particularly sensitive to light and nutrients availability, and to the physical characteristics of water flow (Horner et al., 1990; Stevenson, 1996). On the one hand, increments in some factors such as light availability, concentrations of inorganic nutrients, temperature and water velocity, usually have a positive effect on biofilm development, that gets expressed as a proliferation in algal and bacterial biomass and elevated metabolism (e.g. Horner and Welch, 1981; Guasch et al., 1995; Dodds et al., 2002; Olapade and Leff, 2005), along with reductions in the proportion of carbohydrates (e.g. Freeman and Lock, 1995; Sutherland, 2001), and the proliferation of polysaprobic and eutrophic species. On the other hand, increments in other factors such as water velocity or turbidity usually have the opposite effects on the community (e.g. von Schiller et al., 2007; Romaní and Sabater, 2000; DaviesColley and Smith, 2001).

Research concerning the responses of the epipelic biofilms (those that develop on fine sediments) to environmental changes in template areas is scarce (Sierra and Gómez, 2007; 2010; 2013; Gómez et al., 2009; Cochero et al., 2013). In natural streams, however, biofilms are almost always subjected to multiple stressors that influence the overall water quality rather than to the modifications of a single factor (Breitburg et al., 1998; Venter et al., 2006; Halpern et al., 2007, 2008; Crain et al., 2008). Therefore, the aim of this study was to explore the possible responses of epipelic biofilms to two distinct environmental conditions, with joint increments of nutrients, temperature, water velocity and turbidity.

For this purpose, biofilms from a stream with little human impact were exposed to two environmental conditions, named Low and High treatment, that combined increments in temperature, nutrients (phosphorous and nitrogen), turbidity and water velocity. Changes in the structure and metabolism of the epipelic biofilms were measured for five weeks, predicting growth in both algal and bacterial biomasses and total respiration, declines in the total concentration of carbohydrates in the sediment, and changes in the specific composition that favor species tolerant to more eutrophic conditions.

\section{Materials and methods}

A laboratory experiment in artificial channels was carried out using epipelic biofilm from a site in the "Martin Stream" ( $34^{\circ} 54^{\prime} 51^{\prime}$ " S - 58 $04^{\prime}$ '39" W), which is exposed to the impact of low agricultural activity. The water quality of the site (Table 1) was assessed $a$ priori by the concentrations of Soluble Reactive Phosphorous (SRP, mg P L ${ }^{-1}$ ), Dissolved 
Inorganic Nitrogen (DIN, mg $\mathrm{N} \mathrm{L}^{-1}$ ), Dissolved Oxygen (DO, $\mathrm{mg} \mathrm{L}^{-1}$ ), Biochemical Oxygen Demand $\left(\mathrm{BOD}_{5}\right.$, $\mathrm{mg} \mathrm{L}^{-1}$ ) and Chemical Oxygen Demand (COD, mg L $\mathrm{L}^{-1}$ ) (Bartram and Balance, 1996).

Table 1. Dissloved oxygen conncentration (DO), soluble reactive phosphorous (SRP), disolved inorganic nitrogen (DIN), biochemical oxygen demand $\left(\mathrm{BOO}_{5}\right)$ and chemical oxygen demand (COD) measured in the "Martin" stream before the experimental stage.

\begin{tabular}{lc}
\hline Temperature $\left({ }^{\circ} \mathrm{C}\right)$ & $23.43( \pm 0.68)$ \\
$\mathrm{pH}$ & $8.77( \pm 0.02)$ \\
Conductivity $\left(\mu \mathrm{S} \mathrm{cm}^{-1}\right)$ & $1536( \pm 4.12)$ \\
$\mathrm{DO}\left(\mathrm{mg} \mathrm{L}^{-1}\right)$ & $7.70( \pm 0.25)$ \\
$\mathrm{SRP}\left(\mathrm{mg} \mathrm{P} \mathrm{L}^{-1}\right)$ & $0.37( \pm 0.01)$ \\
$\mathrm{DIN}\left(\mathrm{mg} \mathrm{N} \mathrm{L}^{-1}\right)$ & $0.22( \pm 0.05)$ \\
$\mathrm{BOD}\left(\mathrm{mg} \mathrm{L}^{-1}\right)$ & $6( \pm 0.11)$ \\
$\mathrm{COD}\left(\mathrm{mg} \mathrm{L}^{-1}\right)$ & $15( \pm 0.57)$ \\
\hline
\end{tabular}

Nine indoor artificial channels measuring $1 \mathrm{~m}$ (length) x $0.15 \mathrm{~m}$ (width) $\mathrm{x}$ $0.10 \mathrm{~m}$ (height) were used, each with an access ramp (40 slope) that ensures a laminar input flow (water depth was $0.10 \mathrm{~m}$ ). Water exiting the channel flowed through a slit, and fell into a holding reservoir before being pumped back to the access ramp (Figure 1). All artificial channels were exposed to a photoperiod of $14 \mathrm{~h}$ light-10 h dark. Light was provided by GE® E-biax Helical lights $\left(6,500^{\circ} \mathrm{K}\right.$, IRC82\%) with an intensity of 110 $115 \mu \mathrm{E} \mathrm{m}^{-2} \mathrm{~s}^{-1}$ of photosynthetically active radiation.

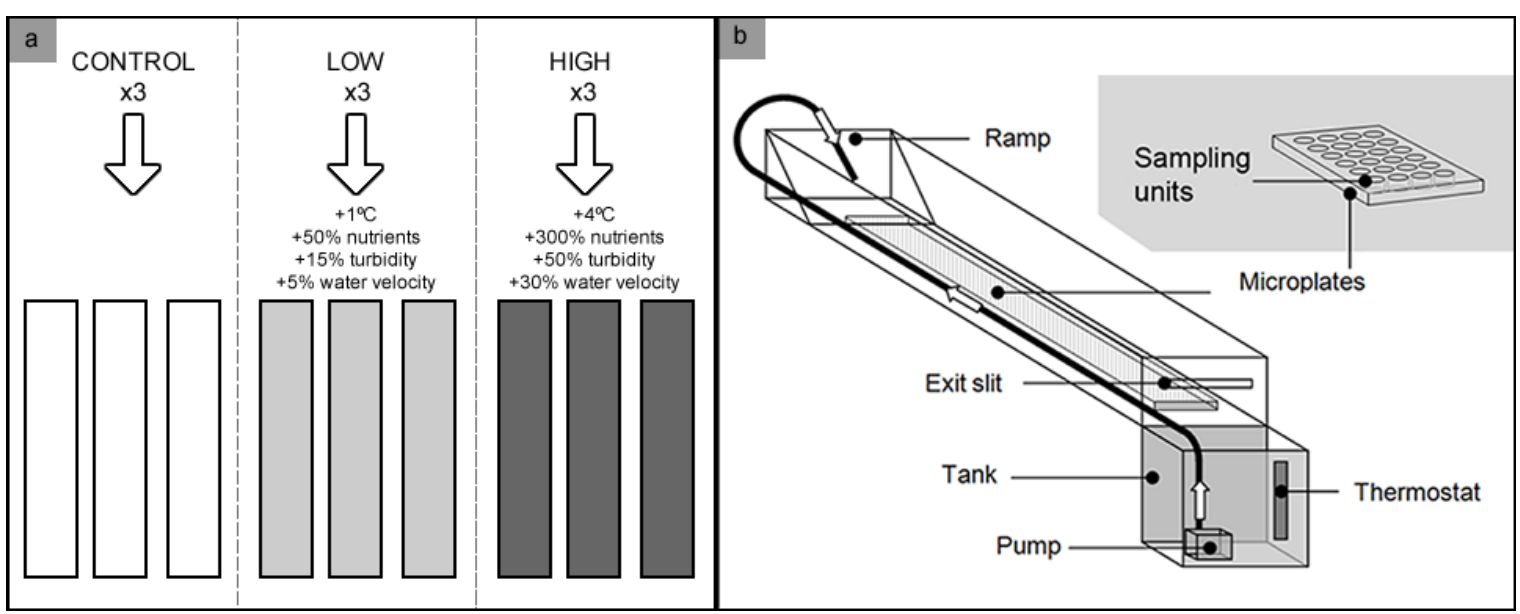

Figure 1. Experimental design employed (a) and schematics of one of the nine artificial channels used in the experiments (b). The physical-chemical variables in the control channels were kept similar to the values obtained in the field, while the treatment channels were exposed to the combined increments in four variables in two distinct levels.

Out of the nine channels, three were used as controls (C) and their physicalchemical variables were kept similar to the values measured at the stream. Another three channels (HIGH treatment) were exposed to a $4^{\circ} \mathrm{C}$ increase in temperature, $300 \%$ increase in nutrients (SRP and DIN), $50 \%$ increase in suspended solids and 20\% increase in water velocity. These values were selected as they represent a realistic 
characteristic of highly eutrophic sites in Pampean streams (Licursi and Gómez, 2002; Gómez et al., 2008; Sierra and Gómez, 2010), and by considering the increments forecasted in temperature and rainfall for the Pampean Region for the next decades (Hulme and Sheard, 1999) and the temperature-runoff relationship (Labat et al., 2004). The last three channels (LOW treatment) were exposed to intermediate levels of the manipulated variables: $1{ }^{\circ} \mathrm{C}$ increase in temperature, $50 \%$ increase in nutrients (SRP and DIN), 15\% increase in suspended solids and 5\% increase water velocity. These values were selected as they represent an intermediate alteration of the experimental variables.

Water temperature increments were achieved using regulated Atman $70 \mathrm{~W}$ water heaters placed in the individual tanks of each artificial channel. The increments in water velocity were achieved by calibrating the Chosen ${ }^{\circledR}$ Champion CX-500 water pumps, also placed in the individual tanks of each channel, at the proper speeds. Increases in turbidity were achieved by adding sterilized suspended solids to each channel from the corresponding stream where the biofilm was collected from. Nutrient increments (SRP and DIN) were achieved by adding dissolved Nitrofoska ${ }^{\circledR}$ fertilizer (of frequent use in the Pampean plain for agricultural purposes, $12 \% \mathrm{~N}-12 \% \mathrm{P}-17 \% \mathrm{~K}$ ) in the appropriate concentration for each channel. For every physical-chemical variable measured, three samples were collected from each channel, and the results obtained for each sample were averaged to be used in all statistical analyses.

For the biofilms to develop, each channel contained Falcon ${ }^{\circledR}$ multiwell polystyrene microplates first filled with sterilized sediment from the sampling site, for a total volume in each well of $3.4 \mathrm{~cm}^{3}$. Biofilm inocules were brought from the sampling site during the summer and added to the microplates, and water from the same site was circulated in each channel for 36 days. Water from all channels was partially renewed with filtered stream water twice a week to prevent metabolite accumulation.

\section{Physical-chemical variables}

Dissolved Oxygen (DO, mg $\mathrm{L}^{-1}$ ), temperature $\left({ }^{\circ} \mathrm{C}\right)$, conductivity $\left(\mu \mathrm{S} \mathrm{cm}{ }^{-1}\right)$ and $\mathrm{pH}$ were measured using a CONSORT C933 sensor. Turbidity (NTU) was measured using an HORIBA U10 sensor, and water velocity $\left(\mathrm{m} \mathrm{s}^{-1}\right)$ using a Schiltknecht MiniAir20. Nutrient samples were filtered through glass fiber filters (Whatman GF/F, Whatman International); ammonia, nitrites, nitrates and soluble reactive phosphorous were analyzed according to standard methods (APHA, 1998). Total dissolved inorganic nitrogen (DIN, mg N L ${ }^{-1}$ ) was calculated as the sum of nitrate, nitrite and ammonia.

\section{Epipelic biofilm sampling}

The epipelic biofilm samples were collected by pipetting the first $10 \mathrm{~mm}$ of the superficial layer $\left(3.14 \mathrm{~cm}^{3}\right)$ from wells selected at random in each channel. Samples for all biological analyses consisted of three subreplicates (three wells). All measurements performed in the biofilm samples were normalized to square centimeters of sand surface area, which was calculated as described in Marxsen and Witzel (1991).

\section{Community analysis}

Three samples from each channel were fixed with formaldehyde (4\%) and used to identify the community composition. Density of consumers and producers of the microbenthic community (size $<1 \mathrm{~mm}$ ) were estimated using a Sedgwick-Rafter chamber (APHA, 1998) in an inverted optical microscope (Olympus $\mathrm{BX} 50$ ) at 400X. The following keys were used for species identification: Bourrely (1966, 1968, 1970), Krammer and LangeBertalot (1986, 1988, 1991a, b), Tell and Conforti (1986), Streble and Krauter (1987), and Komárek and Anagnostidis (1999, 2005).

\section{Chlorophyll-a}

Epipelic biofilm samples were filtered through Sartorious GF/C filters. 
Samples were sonicated for $2 \mathrm{~min}$ in a Cleanson CS-1106 sonicator and filters were stored in the dark and frozen until they were analyzed. Chlorophyll- $a$ ( $\mathrm{mg} \mathrm{cm}^{-2}$ ) was then extracted with $90 \%$ acetone for $12 \mathrm{~h}$. The supernatant was read in a UVVIS Auto 2602 spectrophotometer, and the concentration was calculated according to Strickland and Parsons (1968).

\section{Bacterial biomass}

Epipelic biofilm samples were stored in sterile glass vials with formalin $2 \% \mathrm{v} / \mathrm{v}$. Bacterial density was estimated after sonication (three 2 min cycles) and appropriate dilution (1:100 to 1:400) of the samples. Diluted samples were stained for 10 min with DAPI (4',6-diamidino-2phenyilindole) to a final concentration of 1 $\mu \mathrm{g} \mathrm{mL}{ }^{-1}$ (Porter and Feig, 1980), and filtered through a $0.2 \mu \mathrm{m}$ black polycarbonate filter (GE Osmonics). Bacteria were then counted using an epifluorescence microscope (Olympus BX50) under 1,000x magnification. Twenty fields were counted for a total of 400 to 800 organisms per replicate. Bacterial biovolume was calculated assuming a $0.1 \mu \mathrm{m}^{3}$ constant volume per bacterial cell (Romaní et al., 2009), and bacterial biomass $\left(\mu \mathrm{gC} \mathrm{cm}^{-2}\right)$ was calculated from bacterial cell biovolume using the conversion factor

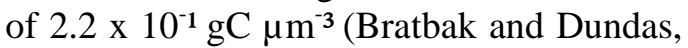
1984).

\section{Ash-free dry weight}

Samples were dried for $48 \mathrm{~h}$ at $60{ }^{\circ} \mathrm{C}$, weighed, ashed for $3 \mathrm{~h}$ at $550{ }^{\circ} \mathrm{C}$, and re-weighed to determine the ash-free dry weight (AFDW) content (APHA, 1998).

\section{Total carbohydrates}

Epipelic biofilm samples were ground in $5 \mathrm{~mL}$ of $1 \mathrm{M} \mathrm{H}_{2} \mathrm{SO}_{4}$ with a glass rod in glass tubes, covered in aluminum foil and placed in a thermobath at $100{ }^{\circ} \mathrm{C}$ for an hour. An aliquot of $1 \mathrm{~mL}$ was separated from the supernatant and $1 \mathrm{~mL}$ of $5 \%$ phenol and $5 \mathrm{~mL}$ of concentrated $\mathrm{H}_{2} \mathrm{SO}_{4}$ were then added. After allowing the tubes to cool down for 30 min the samples were read in a UV-VIS Auto 2602 spectrophotometer at $485 \mathrm{~nm}$ (based on Dubois et al., 1956). Total carbohydrate $\left(\mu \mathrm{gL}^{-1}\right)$ values were obtained using a glucose calibration curve.

\section{Total respiratory activity}

The activity of the electron transport system (ETS) was assayed by measuring the reduction of the electron transport acceptor INT (2-3 tetrazolium chloride) into INT-formazan (iodonitrotetrazolium formazan) (Blenkinsopp and Lock, 1990). Epipelic biofilm samples were incubated for $12 \mathrm{~h}$ on a shaker in the dark with $0.02 \%$ INT (2-(4-Iodophenyl)-3-(4nitrophenyl)-5-phenyltetrazolium chloride) at room temperature. To terminate the reaction, $8 \mathrm{~mL}$ of methanol at $4{ }^{\circ} \mathrm{C}$ were added, and samples were filtered through Sartorious GF/C filters before reading them in a UV-VIS Auto 2602 spectrophotometer at $480 \mathrm{~nm}$ (Blenkinsopp and Lock, 1990). Total respiratory activity values (mg formazan $\mathrm{cm}^{-2} \mathrm{~h}^{-1}$ ) were calculated using an INT-formazan calibration curve (Sigma I7375).

\section{Data analysis}

Significant differences for the measured biological variables were analyzed using a two-way repeated measures analysis of variance (RM ANOVA) to test for the differences among treatments and dates (Winer, 1971). Homogeneity of variances was first checked using Cochrane's test, and probabilities within groups were corrected for sphericity using the GreenhouseGeisser correction. Differences in the physical-chemical variables between treatments were analyzed using a one-way ANOVA, and the same analysis was used to monitor that the manipulated variables fell within the planned values. All post-hoc comparisons were made by StudentNewman-Keuls Test (SNK), and generalized eta ${ }^{2}\left(\eta_{G}{ }^{2}\right)$ was computed as a measure of the effect size (Olejnik and Algina, 2003). This statistic has two major advantages over the traditional eta $^{2}$ and partial-eta ${ }^{2}$ : first, it provides measures of effect size that are comparable across a wide variety of research designs; and 
second, these effect-size measures provide indices of effect that are consistent with Cohen's (1998) guidelines for defining the magnitude of the effect (Olejnik and Algina, 2003). These guidelines state that an effect size $\leq 0.20$ is considered small, around 0.50 is considered a medium effect, and $\geq 0.80$ is a large effect. $\eta_{\mathrm{G}}{ }^{2}$ provides comparability across between-subjects and within-subjects in repeated measures designs (Bakeman, 2005), and is estimated as:

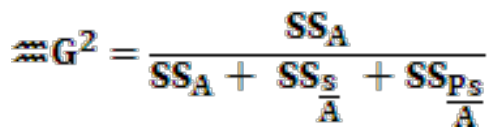

where: SS represents a Sums of Squares, $A$ represents a between-subjects factor (Treatment), $P$ represents a within-subjects factor (Time) and $s$ represents the subjects factor.

Also, the overall differences between the controls and treatments in the composition (autotrophs and consumers) were analyzed conducting an Analysis of Similarity (ANOSIM), and a two-way similarity percentage analysis (SIMPER), based on the Bray-Curtis similarity measurement was used to determine the percent contribution of each taxon to the average dissimilarity between groups across all times (Clarke 1993).

\section{Results}

\section{Physical-chemical parameters}

The values obtained for the physical-chemical variables measured in the sampling site were used as the target values for the control channels in the laboratory. The manipulated variables in the channels (SRP, DIN, temperature, water velocity and turbidity) were significantly increased in both LOW and HIGH treatments when compared to the controls $(\mathrm{p}<0.05$, Table $2)$. Results from the analysis of variance show that these increments were in accordance with the planned increments for the experiment.

Table 2. Mean \pm standard deviation of the physical-chemical variables measured in the experiment. A posteriori test Student-Neuman-Keuls (SNK) are shown when significant differences were found.

\begin{tabular}{|c|c|c|c|c|}
\hline & \multicolumn{3}{|c|}{ Mean ( \pm SD) } & \multirow{2}{*}{ SNK } \\
\hline & C & LOW & HIGH & \\
\hline $\mathrm{pH}$ & $8.7( \pm 0.1)$ & $8.6( \pm 0.1)$ & $8.5( \pm 0.2)$ & \\
\hline Conductivity $\left(\mu S \mathrm{~cm}^{-1}\right)$ & $633.6( \pm 256.7)$ & $723.5( \pm 266.8)$ & $1,075.4( \pm 292.4)$ & $C=L O W<H I G H$ \\
\hline $\mathrm{DO}\left(\mathrm{mg} \mathrm{L}^{-1}\right)$ & $7.7( \pm 0.02)$ & $7.7( \pm 0.02)$ & $7.6( \pm 0.02)$ & - \\
\hline Temperature $\left({ }^{\circ} \mathrm{C}\right)$ & $24.7( \pm 1.3)$ & $25.8( \pm 1.2)$ & $28.9( \pm 1.4)$ & $C<L O W<H I G H$ \\
\hline Turbidity (NTU) & $32.3( \pm 7.5)$ & $36.9( \pm 8.1)$ & $48.3( \pm 10.8)$ & $C=L O W<H I G H$ \\
\hline Water Velocity ( $\mathrm{m} \mathrm{s}^{-1}$ ) & $0.35( \pm 0.01)$ & $0.37( \pm 0.01)$ & $0.43( \pm 0.01)$ & $C<L O W<H I G H$ \\
\hline $\mathrm{SRP}\left(\mathrm{mg} \mathrm{L}^{-1}-\mathrm{P}\right)$ & $0.20( \pm 0.12)$ & $0.327( \pm 0.19)$ & $0.891( \pm 0.53)$ & $C<L O W<H I G H$ \\
\hline DIN (mg L-1-N) & $0.43( \pm 0.40)$ & $0.75( \pm 0.65)$ & $1.39( \pm 1.30)$ & $C<L O W<H I G H$ \\
\hline
\end{tabular}

$\mathrm{C}=$ Control, LOW = Low treatment, HIGH = High treatment.

\section{Bacterial biomass}

The bacterial biomass remained unvaried throughout the first three weeks in all channels, and increased in the fourth week indistinctly from the treatments (Figure 2a). The biomass in the controls had a mean of $16.64( \pm 25.96) \mu g C \mathrm{~cm}^{-2}$, of $24.61( \pm 44.08) \mu g C \mathrm{~cm}^{-2}$ in the LOW channels and of $30.09( \pm 69.45) \mu g C \mathrm{~cm}^{-2}$ in the HIGH channels; the variation in the parameter throughout the experiment was high $\left(\eta_{\mathrm{G}^{2}}=0.64\right)$ (Table 3).

\section{Algal biomass}

The chlorophyll- $a$ concentration in the channels remained similar throughout the experiment in all channels (Figure 2b). The mean values in the controls $\left(0.41 \pm 0.23 \mathrm{mg} \mathrm{cm}^{-2}\right)$ were not significantly different from the values in the LOW 
treatment $\left(0.42 \pm 0.21 \mathrm{mg} \mathrm{cm}{ }^{-2}\right)$ or the HIGH treatment $\left(0.33 \pm 0.14 \mathrm{mg} \mathrm{cm}^{-2}\right)$.

\section{Ash-free dry weight}

The mean ash-free dry weight values were of $0.03( \pm 0.01) \mathrm{mg} \mathrm{cm}^{-2}$ in the controls, of $0.05( \pm 0.08) \mathrm{mg} \mathrm{cm} \mathrm{cm}^{-2}$ in the LOW channels, and of $0.07( \pm 0.11) \mathrm{mg} \mathrm{cm}^{-}$ 2 in the HIGH channels. The variation of this parameter throughout the experiment (Figure 2c) was similar to the one measured in the bacterial biomass, which suggests that the bacterial community is responsible for most of the organic matter content in the samples. However, there were no significant differences between the treatments and the controls (Table 3).

\section{Total respiratory activity}

The total respiration values, as measured by the electron transport system, showed a mean value of $20.41( \pm 19.51) \mu \mathrm{g}$ formazan $\mathrm{cm}^{-2} \mathrm{~h}^{-1}$ in the controls, of 16.67
$( \pm 10.61) \mu \mathrm{g}$ formazan $\mathrm{cm}^{-2} \mathrm{~h}^{-1}$ in the LOW channels and of $12.57( \pm 8.01) \mu \mathrm{g}$ formazan $\mathrm{cm}^{-2} \mathrm{~h}^{-1}$ in the HIGH channels (Figure 2d). The response in this variable was dependant on the sampling time (significant Treatment*Date interaction in Table 3), being significantly higher in the controls in the first two weeks (one-way ANOVA, $\mathrm{p}<0.05$ ).

\section{Total carbohydrates}

The concentration of total carbohydrates had a mean value of 1329 $( \pm 1662) \mu \mathrm{gC} \mathrm{cm}^{-2}$ in the controls, of 1526 $( \pm 1799) \mu \mathrm{gC} \mathrm{cm}^{-2}$ in the LOW channels and of $1535( \pm 1797) \mu \mathrm{gC} \mathrm{\textrm {cm } ^ { - 2 }}$ in the HIGH channels. Although the total carbohydrate concentration was not significantly different between each treatment (Table 3), attributed to the large variability of the parameter throughout the experiment $\left(\eta_{\mathrm{G}}{ }^{2}=0.79\right)$, their concentration increased by the final two weeks in all channels (Figure 2e).

Table 3. Repeated measures ANOVA summary results for the biological variables examined in the experiment, considering two factors: Treatment (Control, Low, High) and Date (1 through 6). Measures of the biological effect are also shown $\left(\eta_{\mathrm{G}}{ }^{2}\right)$, and significant differences are highlighted in bold $(\mathrm{p}<0.05)$.

\begin{tabular}{lcccccc}
\hline \multirow{2}{*}{ Source of variation } & \multicolumn{2}{c}{ Treatment } & \multicolumn{2}{c}{ Date } & \multicolumn{2}{c}{ Treatment x Date } \\
& $\boldsymbol{p}$ & $\boldsymbol{\eta}_{\mathbf{G}}{ }^{2}$ & $\boldsymbol{p}$ & $\eta_{\mathbf{G}}{ }^{2}$ & $\boldsymbol{p}$ & $\eta_{\mathbf{G}}{ }^{2}$ \\
\hline Bacterial biomass & 0.90 & 0.01 & $\mathbf{0 . 0 1}$ & 0.64 & 0.92 & 0.03 \\
Chlorophyll- $a$ & 0.29 & 0.09 & 0.08 & 0.30 & 0.25 & 0.30 \\
Ash-free dry weight & 0.27 & 0.10 & $\mathbf{0 . 0 4}$ & 0.46 & 0.25 & 0.32 \\
Total respiratory activity & 0.30 & 0.18 & $\mathbf{0 . 0 3}$ & 0.30 & $\mathbf{0 . 0 1}$ & 0.69 \\
Carbohydrates & 0.90 & 0.01 & $\mathbf{0 . 0 1}$ & 0.79 & 0.94 & 0.02 \\
\hline Autotrophs & & & & & & \\
$\quad$ Diatoms & 0.71 & 0.14 & 0.24 & 0.14 & 0.54 & 0.13 \\
$\quad$ Clorophytes & 0.86 & 0.02 & 0.63 & 0.04 & 0.46 & 0.17 \\
$\quad$ Euglenophytes & 0.06 & 0.11 & 0.49 & 0.10 & 0.33 & 0.29 \\
$\quad$ Cyanophytes & 0.52 & 0.05 & 0.09 & 0.30 & 0.66 & 0.12 \\
\hline Consumers & & & & & & \\
$\quad$ Nematods & 0.22 & 0.16 & 0.33 & 0.12 & 0.34 & 0.23 \\
$\quad$ Cladocerans & 0.62 & 0.02 & 0.26 & 0.18 & 0.29 & 0.29 \\
$\quad$ Rotifers & 0.55 & 0.04 & 0.43 & 0.10 & 0.35 & 0.25 \\
$\quad$ Protozoans & 0.17 & 0.09 & 0.67 & 0.06 & 0.48 & 0.21 \\
\hline
\end{tabular}

\section{Community composition}

The most represented autotrophs throughout the experiment in all channels were diatoms (Figure 3), mainly Surirella linearis Smith, Denticula elegans Kützing, Navicula erifuga Lange-Bertalot, Nitzschia frustulum (Kützing) Grunow var. frustulum, and Placoneis clementis (Grunow) Cox). 

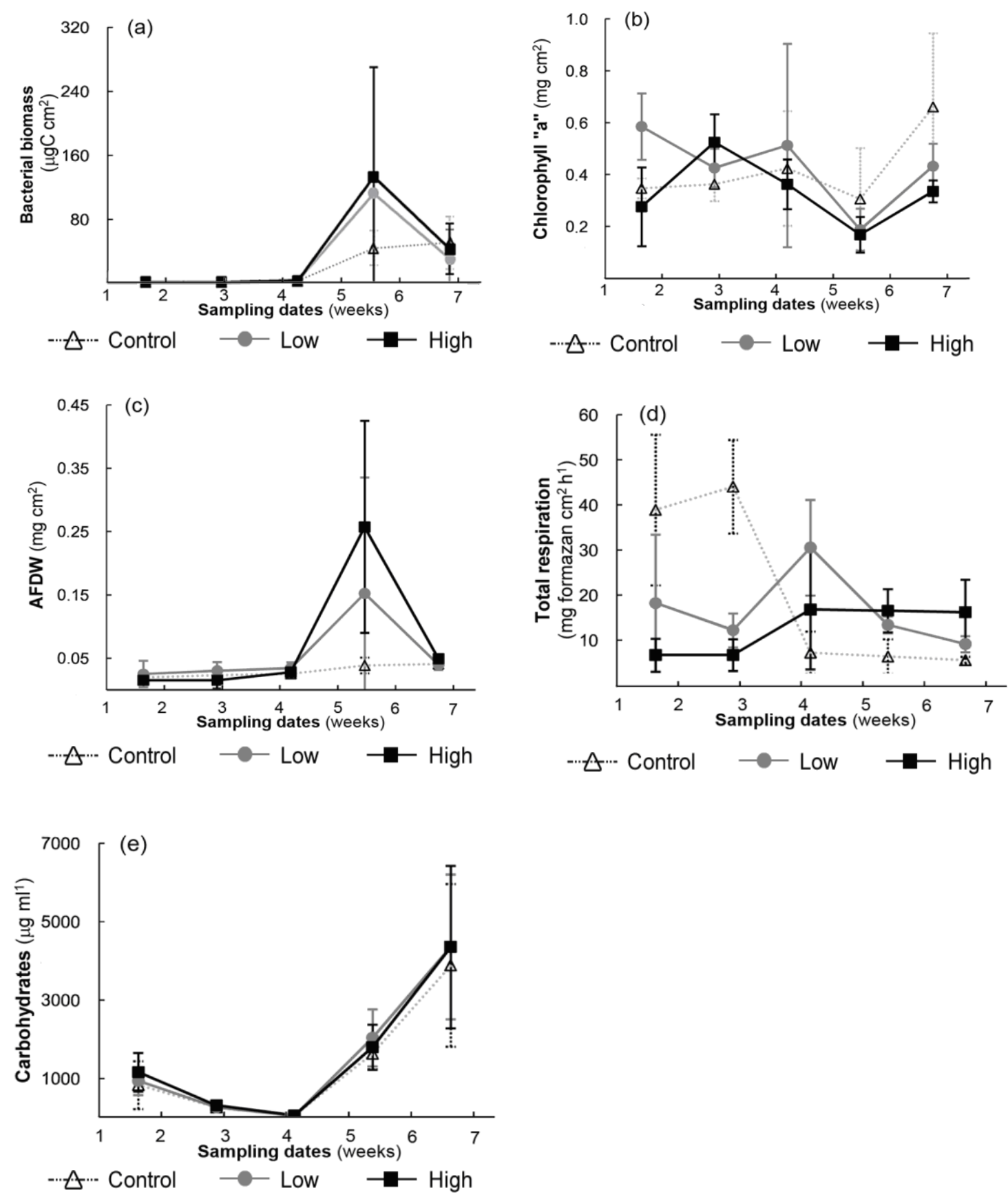

Figure 2. Variations in the biological variables measured througout the experiment: (a) Bacterial biomass; (b) Chlorophyll- $a$ concentration; (c) AFDW; (d) Total respiration; (e) Total carbohydrates. Bars indicate standard deviation.

In abundance, the diatoms were followed by cyanophytes, mainly Oscillatoria tenuis Agardh ex Gomont, and chlorophytes, mainly Coelastrum microporum Nägeli in A. Braun, Scenedesmus opoliensis Richter and Pediastrum duplex Meyen. Euglenophytes, although scarce, were represented by
Euglena acus (Müller) Ehrenberg and species of the genus Phacus Ehrenberg. The abundance of the different algal groups did not exhibit significant differences between the controls and the treatments (Table 3).

Among the consumers, the nematods were the most abundant in all 

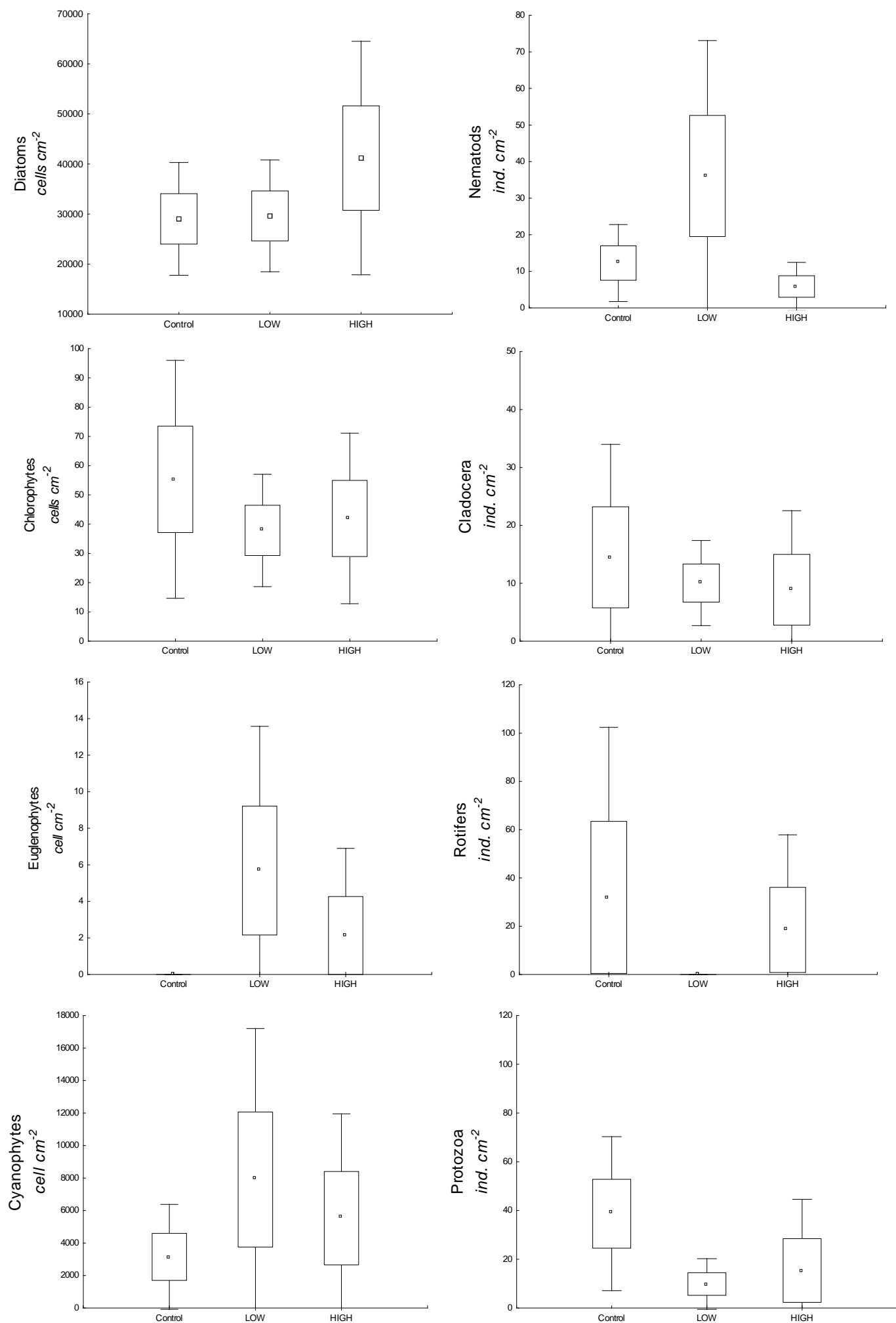

Figure 3. Total densities of autotrophs (left panels) and consumers (right panels) in the controls, LOW and HIGH treatments, represented as mean values (point), standard error (boxes) and standard deviation (bars). 
channels, followed by cladocerans and protozoans (ciliates and testate amoebae), while rotiferans were the least abundant (Figure 3). However, no significant differences were found in these groups due to the treatments (Table 3 ).

The ANOSIM results showed significant differences between the controls and the LOW treatment $(\mathrm{p}=0.04)$ and between the controls and the HIGH treatment $(p=0.03)$ when considering the species composition. The average dissimilarity between the controls and the LOW treatment was slightly lower (71.9\%) than the dissimilarity between the controls and the HIGH treatment (73.2\%), and the taxa that contributed more to the dissimilarity between the groups belonged to the autotrophs, particularly diatoms and cyanobacteria (Table 4).

Table 4. Percentage of dissimilitude between the controls and both treatments, and percentage of contribution of the species that contributed most to the dissimilarity between treatments (Control vs. Low treatment and Control vs. High treatment) as expressed by the SIMPER results.

\begin{tabular}{lcc}
\hline & $\begin{array}{c}\text { Control vs. LOW } \\
\text { (\% dissimilitude) }\end{array}$ & $\begin{array}{c}\text { Control vs. HIGH } \\
\text { (\% dissimilitude) }\end{array}$ \\
\hline Total dissmilitude & 71.9 & 73.2 \\
\hline Oscillatoria tenuis Agardh ex Gomont & 12 & 17 \\
Nitzschia palea (Kützing) Smith & 7 & 8 \\
Ulnaria ulna (Nitzsch.) Compère & 8 & 12 \\
Nitzschia linearis Smith & 6 & 13 \\
Diadesmis converfacea Kützing & 6 & 13 \\
Sellaphora seminulum (Grunow) Mann & 2 & 8 \\
Placoneis placentula (Ehrenberg) Heinzerling & 4 & 8 \\
Nitzschia amphibia Grunow & 2 & 3 \\
Calloneis bacillum (Grunow) Cleve & 2 & 3 \\
Planothidium lanceolatum Lange-Bertalot & 2 & 3 \\
\hline
\end{tabular}

\section{Discussion}

The results from this study show that only the specific composition of the autotrophic assemblage changed in the analyzed time period, as indicated by increase in the dissimilitude between the control and treatments. Although the structural parameters of biofilms are usually last to be affected by changes in the environment, the species' composition within the biofilm was significantly impacted by the treatments, reaching dissimilitude values of $71.9 \%$ due to the low impact treatment, and $73.2 \%$ due to the more intense treatment. Density variations in species such as Oscillatoria tenuis, Nitzschia palea, Ulnaria ulna, Nitzschia linearis, Diadesmis converfacea, Sellaphora seminulum and Placoneis placentula, which proliferate in eutrophic conditions (Palmer 1969; Van Dam et al., 1994; Licursi et al., 2016), contributed the most to the variability between the controls and both treatments.

These changes led to a modification in the autotrophic assemblage, with rises in species most tolerant to a worse habitat and water quality condition, in only a few weeks of the experiment. Similar changes were recorded in a field nutrient addition in a Pampean stream (Artigas et al., 2013; Cochero et al., 2013), where the basal phosphorous levels were tripled, and rapid occurring changes were observed in the algal assemblage, particularly in the proportion of diatoms as a consequence of the input of nutrients to the system (Licursi et al., 2016), while the bacterial biomass and its metabolic activity took longer periods of time to be significantly affected (Cochero et al., 2013).

Although it has been reported that the co-occurrence of the increments in temperature and nutrients lead to metabolic and structural responses in epilithic 
biofioms in short exposition periods (60 days) (Villanueva et al., 2011), and similar responses are caused by nutrients and water current velocity (Horner and Welch, 1981), the changes in the total respiratory activity in this experiment, with an epipelic biofilm exposed to a greater number of stressors, were not evident immediately. The dependence of bacteria for autochthonous organic matter in Pampean streams (Cochero et al., 2013) suggests that this heterotrophic community needs longer exposition times to show significant changes in the biofilm. On the other hand, the effect of nutrients alone can be less predictable in ecosystems with higher basal nutrient levels, such as Pampean streams. Although changes are slow, it is possible that the chronic input of nutrients will affect the functioning and the services that these water bodies provide (Artigas et al., 2013). Our results show that the epipelic biofilms subjected to the co-occurrence of several constant stress factors reveal that the specific composition of the autotroph assemblage responds sensitively at short term exposures, in comparison with the other variables analyzed.

Pampean streams are subject to a growing demographic pressure, and the expansion of cultivated land along with the effects of global changes might have significant effects in temperature and rainfall patterns that influence these lotic systems. Therefore, the combination of studies with various temporal and spatial scales can provide with a more precise comprehension of the factors that determine the development and dynamics of these epipelic communities. Studies that include the effects of multiple stressors in freshwater communities, such as those carried out by Ormerod et al. (2010), Proia (2012), Piggott et al. (2012), Lange et al. (2014), Piggott et al. (2015), require a more intricate and complex experimental design than the one employed in this article, to be able to identify the individual contribution of each environmental variable. However, the results shown in this article increase the current knowledge of the overall effects of co-occurring variables on epipelic biofilms of these nutrient rich streams, and highlights the sensitivity of the specific composition to measure rapid changes in water quality.

\section{Conclusion}

In summary, this study shows that the responses of nutrient-rich biofilms to the effects of co-occurring physicalchemical changes are not easily predictable, since they do not necessarily coincide with the results obtained in the large variety of studies that modified the same physicalchemical variables in an individual manner. This could be the result of the inherent resistance of nutrient-rich biofilms to stressors, or could be a consequence of an antagonistic interaction between the manipulated variables.

However the case, more research that includes the effects of multiple stressors is needed to understand how the biofilms respond in natural settings, where the variations of a single variable due to either environmental or human-induced factors are unusual. Also, these results highlight the sensitivity of communitybased bioindicators, such as species composition, to environmental changes at short term experiments.

\section{Acknowledgements}

This study was funded by project PIP No. 296 of the Consejo Nacional de Investigaciones Científicas y Técnicas (CONICET - Argentina).

\section{Conflict of interest statement}

Authors declare that they have no conflict of interests.

\section{References}

APHA. Standard methods for examination of water and wastewater. 20 ed. Washington: American Public Health Association, American Water Works Association and Water Pollution Control Federation, 1998.

Artigas, J.; García-Berthou, E.; Bauer, D. E.; Castro, M. I.; Cochero, J.; Colautti, D. C.; Cortelezzi, A.; Donato, J. C.; Elosegi, A.; 
Feijoó, C. Global pressures, specific responses, effects of nutrient enrichment in streams from different biomes. Environmental Research Letters, v. 8, no. 1, 13 p, 2013. http://dx.doi.org/10.1088/1748-9326/8/1/014002

Bakeman R. Recommended effect size statistics for repeated measures designs. Behaviour Research and Methods, v. 37, no. 3, p. 379384, 2005. http://dx.doi.org/10.3758/BF03192707

Bartram, J.; Ballance, R. (Eds.). Water quality monitoring: A practical guide to the design and implementation of freshwater quality studies and monitoring programmes. London: UNESCO, WHO and UNEP, 1996. Available from: <http://www.who.int/water_sanitation_ health/resourcesquality/wqmonitor/en>.

Accessed in: Feb. 08, 2016.

Blenkinsopp, S. A.; Lock, M. A. The measurement of electron transport system activity in river biofilms. Water Research, v. 24, p. 441-445, 1990.

Bonnineau, C.; Guasch, H.; Proia, L.; Ricart, M.; Geiszinger, A.; Romaní, A. M.; Sabater, S. Fluvial biofilms: A pertinent tool to assess $\beta$ blockers toxicity. Aquatic Toxicology, v. 96, no. 3, p. 225-233, 2010. http://dx.doi.org/10.1016/j.aquatox.2009.10.024

Bourrelly, P. Les algues d'eau douce. Tome I: Algues vertes. Paris: Éditions N. Boubée \& Cie., 1966.

Bourrelly, P. Les algues d'eau douce. Tome II: Algues jaunes et brunes. Paris: Éditions N. Boubée \& Cie., 1968.

Bourrelly, P. Les algues d'eau douce. Tome III: Algues bleues et rouges. Paris: Éditions N. Boubée \& Cie., 1970.

Bratbak, G.; Dundas, I. Bacterial dry matter content and biomass estimations. Appl. Environmental Microbiology, v. 48, no. 4, p. 755-757, 1984.

Breitburg, D. L.; Baxter, J. W.; Hatfield, C.; Howarth, R. W.; Jones, C. G.; Lovett, G. M.; Wigand, C. Understanding effects of multiple stressors: ideas and challenges. In: Pace, M.; Groffman, P. (Eds.). Successes, limitations and frontiers in ecosystem science. New York: Springer, 1998. p. 416-431.

Clarke, K. R. Non parametric multivariate analyses of changes in community structure. Australian Journal of Ecology, v. 18, p. 117143, 1993.

Cochero, J.; Romaní, A. M.; Gómez, N. Delayed response of microbial epipelic biofilm to nutrient addition in a Pampean stream.
Aquatic Microbial Ecology, v. 69, no. 2, p. 145-155, 2013. http://dx.doi.org/10.3354/ame01630

Cohen, J. Statistical power analysis for the behavioral sciences. 2 . ed. New York: Academic Press, 1988.

Crain, C. M. Interactions between marsh plant species vary in direction and strength depending on environmental and consumer context. Journal of Ecology, v. 96, no. 1, p. 166-173, $2008 . \quad$ http://dx.doi.org/10.1111/j.13652745.2007.01314.x

Davies-Colley, R. J.; Smith, D. G. Turbidity, suspended sediment, and water clarity, a review. Journal of American Water Resources, v. 37, no. 5, $\quad$ p. 1085-1101, 2001. http://dx.doi.org/10.1111/j.1752-

1688.2001.tb03624.x

Davies-Colley, R. J.; Quinn, J. M.; Hickey, C. W.; Ryan, P. A. Effects of clay discharges on streams. 1. Optical properties and epilithon. Hydrobiologia, v. 248, no. p. 215-234, 1992. http://dx.doi.org/10.1007/BF00006149

Dodds, W. K.; Smith, V. H.; Lohman, K. Nitrogen and phosphorus relationships to benthic algal biomass in temperate streams. Canadian Journal of Fisheries and Aquatic Sciences, v. 59, no. 5, p. 865-874, 2002. http://dx.doi.org/10.1139/f02-063

Dubois, M.; Gilles, K. A.; Hamilton, J. K.; Rebers, P. A.; Smith, F. Colorimetric method for determination of sugars and related substances. Analytical Chemistry, v. 28, no. 3, p. 350-356, 1956. http://dx.doi.org/10.1021/ac60111a017

Feijoó, C. S.; Lombardo, R. J. Baseline water quality and macrophyte assemblages in Pampean streams: a regionnal approach. Water Research, v. 41, no. 7, p. 1399-1410, 2007. http://dx.doi.org/10.1016/j.watres.2006.08.026

Freeman, C.; Lock, M. A. The biofilm polysaccharide matrix: a buffer against changing organic substrate supply? Limnology and Oceanography, v. 40, no. 2, p. 273-278, 1995.

http://dx.doi.org/10.4319/lo.1995.40.2.0273

Giorgi, A.; Feijoó, C.; Tell, G. Primary producers in a Pampean stream: temporal variation and structuring role. Biodiversity \& Conservation, v. 14, no. 7, p. 1699-1718, 2005. http://dx.doi.org/10.1007/s10531-004-0694-z

Gómez, N.; Sierra, M. V.; Cortelezzi, A.; Rodrigues Capítulo, A. Effects of discharges from the textile industry on the biotic integrity of benthic assemblages. Ecotoxicology and 
Environmental Safety, v. 69, no. 3, p. 472-479, 2008.

http://dx.doi.org/10.1016/j.ecoenv.2007.03.007

Gómez, N.; Donato, J. C.; Giorgi, A.; Guasch, H.; Mateo, P.; Sabater, S. La biota de los ríos: los microorganismos autótrofos. In: Elosegui, A.; Sabater, S. Conceptos y técnicas en ecología fluvial. Bilbao: Fundación BBVA, 2009. p. 219-242. Available from: <http://www.fbbva.es/TLFU/microsites/ecologi a_fluvial/pdf/cap_12.pdf $>$. Accessed in: Feb. 08, 2016.

Guasch, H.; Martí, E.; Sabater, S. Nutrient enrichment effects on biofilm Metabolism in a Mediterranean stream. Freshwater Biology, $\begin{array}{lll}\text { v. 33, p. 373-383, } 1995 . & \text {. }\end{array}$ http://dx.doi.org/10.1111/j.1365-

2427.1995.tb00399.x

Halpern, B. S.; Selkoe, K. A.; Micheli, F.; Kappel, C. V. Evaluating and ranking the vulnerability of global marine ecosystems to anthropogenic threats. Conservation Biology,

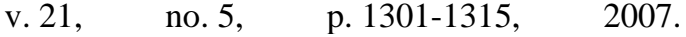
http://dx.doi.org/10.1111/j.1523-

1739.2007.00752.x

Halpern, B. S.; McLeod, K. L.; Rosenberg, A. A.; Crowder, L. B. Managing for cumulative impacts in ecosystem-based management through ocean zoning. Ocean \& Coastal Management, v. 51, no. 3, p. 203-211, 2008. http://dx.doi.org/10.1016/j.ocecoaman.2007.08. 002

Horner, R. R.; Welch, E. B. Stream periphyton development in relation to current velocity and nutrients. Canadian Journal of Fisheries and Aquatic Sciences, v. 38, p. 449-457, 1981. http://dx.doi.org/10.1139/f81-062

Horner, R. R.; Welch, E. B.; Seeley, M. R.; Jacoby, J. M. Responses of periphyton to changes in current velocity, suspended sediment and phosphorus concentration. Freshwater Biology, v. 24, no. 2, p. 215-232, 1990. http://dx.doi.org/10.1111/j.1365-

2427.1990.tb00704.x

Hulme, M.; Sheard, N. Climate change scenarios for Argentina. Norwich, UK: Climatic Research Unit, 1999.

INDEC - Instituto Nacional de Estadística y Censos. Censo Nacional de Población, Hogares y Viviendas 2010. Available from: $<$ http://www.indec.gov.ar $>$. Accessed in: Feb. 08, 2016.

Komárek, J.; Anagnostidis, K. Cyanoprokaryota. 1. Teil: Chroococcales. Jena-Stuttgart-Lübeck-Ulm, Germany: Gustav Fischer, 1999.
Komárek, J.; Anagnostidis, K. Cyanoprokaryota. 2. Teil: Oscillatoriales. Jena-Stuttgart-Lübeck-Ulm, Germany: Gustav Fischer, 2005.

Krammer, K.; Lange-Bertalot, H. Süßwasswasserflora von Mitteleuropa, Bacillariophyceae. 1: Naviculaceae. Stuttgart: Gustav Fischer Verlag, 1986.

Krammer, K.; Lange-Bertalot, H. Süßwasswasserflora von Mitteleuropa, Bacillariophyceae. 2: Bacillariaceae, Epithemiaceae, Surirellaceae. Stuttgart: Gustav Fischer Verlag, 1988.

Krammer, K.; Lange-Bertalot, H. Süßwasswasserflora von Mitteleuropa, Bacillariophyceae. 3: Centrales, Fragilariaceae, Eunotiaceae. Stuttgart: Gustav Fischer Verlag, 1991a.

Krammer, K.; Lange-Bertalot, H. Süßwasswasserflora von Mitteleuropa, Bacillariophyceae. 4: Achnanthaceae, Literaturverzeichnis. Stuttgart: Gustav Fischer Verlag, 1991b.

Labat, D.; Goddéris, Y.; Probst, J. L.; Guyot, J. L. Evidence for global runoff increase related to climate warming. Advances in Water Resources, v. 27, no. 6, p. 631-642, 2004. Available from: <https://core.ac.uk/download/ files/437/12041594.pdf $>$. Accessed in: Feb. 08, 2016.

Lange, K.; Townsend, C. R.; Matthaei, C. D. Can biological traits of stream invertebrates help disentangle the effects of multiple stressors in an agricultural catchment? Freshwater Biology, v. 59, no. 12, p. 2431-2446, 2014. http://dx.doi.org/10.1111/fwb.12437

Licursi, M.; Gómez, N. Benthic diatoms and some environmental conditions in three lowland streams. Annales de Limnologie International Journal of Limnology, v. 38, no. 2, p. 109-118, 2002. Available from: <http://www.limnology-journal.org/articles/ limn/pdf/2002/02/limno20022p109.pdf>. Accessed in: Feb. 08, 2016.

Licursi, M.; Gómez, N.; Sabater, S. Effects of nutrient enrichment on epipelic diatom assemblages in a nutrient-rich lowland stream, Pampa Region, Argentina. Hydrobiologia, v. 766, no. 1, p. 135-150, 2016. http://dx.doi.org/10.1007/s10750-015-2450-7

Lock, M. A.; Wallace, R. R.; Costerton, J. W.; Ventullo, R. M.; Charlton, S. E. River epilithon, toward a structural-functional model. Oikos, v. 42, $\quad$ p. 10-22, 1984. http://dx.doi.org/10.2307/3544604 
Malmqvist, B.; Rundle, S. Threats to the running water ecosystems of the world. Environmental Conservation, v. 29, no. 2, p. 134-153, 2002. http://dx.doi.org/10.1017/S0376892902000097

Marxsen, J.; Witzel, K. P. Significance of extracellular enzymes for organic matter degradation and nutrient regeneration in small streams. In: Chróst, R. J. (Ed.). Microbial enzymes in aquatic environments. New York: Springer-Verlag, 1991. p. 270-285.

Meybeck, M. Carbon, nitrogen and phosphorus transport by world rivers. American J. Science, v. 282, p. 401-450, 1982. http://dx.doi.org/10.2475/ajs.282.4.401

Meybeck, M. Global chemical weathering of surficial rocks estimated from river dissolved loads. American J. Science, v. 287, p. 401-428, 1987. http://dx.doi.org/10.2475/ ajs.287.5.401

Olapade, O. A.; Leff, L. G. Seasonal response of stream biofilm communities to dissolved organic matter and nutrient enrichments. Applied Environmental Microbiology, v. 71, no. 5, p. 2278-2287, 2005. http://dx.doi.org/10.1128/AEM.71.5.22782287.2005

Olejnik, S.; Algina, J. Generalized eta and omega squared statistics, measures of effect size for some common research designs. Psychological Methods, v. 8, no. 4, p. 434-447, $2003 . \quad$ http://dx.doi.org/10.1037/1082989X.8.4.434

Ormerod, S. J.; Dobson, M.; Hildrew, A. G.; Townsend, C. R. Multiple stressors in freshwater ecosystems. Freshwater Biology, v. 55, no. s1, p. 1-4, 2010. http://dx.doi.org/10.1111/j.1365-

2427.2009.02395.x

Palmer, C. M. A composite rating of algae tolerating organic pollution. Journal of Phycology, v. 5, no. 1, p. 78-82, 1968. http://dx.doi.org/10.1111/j.1529-

8817.1969.tb02581.x

Piggott, J. J.; Lange, K.; Townsend, C. R.; Matthaei, C. D. Multiple stressors in agricultural streams: a mesocosm study of interactions among raised water temperature, sediment addition and nutrient enrichment. PloS One, v. 7, no. 11, e49873, 2012. http://dx.doi.org/10.1371/journal.pone.0049873

Piggott, J. J.; Salis, R. K.; Lear, G.; Townsend, C. R.; Matthaei, C. D. Climate warming and agricultural stressors interact to determine stream periphyton community composition. Global Change Biology, v. 21, no. 1, p. 206222, 2015. http://dx.doi.org/10.1111/gcb.12661
Porter, K. G.; Feig, Y. G. The use of DAPI for identifying and counting aquatic microflora. Limnology \& Oceanography, v. 41, p. 595604, 1980.

http://dx.doi.org/10.4319/lo.1980.25.5.0943

Proia, L. Biofilm responses to multiple stressors associated to global change in river ecosystems. Girona: Universitat de Girona, 2012. (Ph.D. Thesis). Available from: <http://dugi-doc.udg.edu/bitstream/handle/ 10256/7351/tlp.pdf $>$. Accessed in: Feb. 08, 2016.

Revenga, C.; Campbell, I.; Abell, R.; de Villiers, P.; Bryer, M. Prospects for monitoring freshwater ecosystems towards the 2010 targets. Philosophical Transactions of the Royal Society B Biological Sciences, v. 360, no. 1454, p. 397-413, 2005. http://dx.doi.org/10.1098/rstb.2004.1595

Rodrigues Capítulo, A.; Gómez, N.; Giorgi, A. D. N.; Feijoó, C. Global changes in Pampean lowland streams (Argentina), implications for biodiversity and functioning. Hydrobiologia, $\begin{array}{lll}\text { v. } 657, \quad \text { no. } 1, & \text { p. } 53-70, & 2010 .\end{array}$ http://dx.doi.org/10.1007/s10750-010-0319-3

Romaní, A. M.; Sabater, S. Influence of algal biomass on extracellular enzyme activity in river biofilms. Microbial Ecology, v. 41, no. 16, $\quad$ p. 16-24, 2000. http://dx.doi.org/10.1007/s002480000041

Romaní, A. M.; Artigas, J.; Camacho, A.; Graça, M. A. S.; Pascoal, C. La biota de los ríos, los microorganismos heterotróficos. In: Elosegui, A.; Sabater, S. (Eds.). Conceptos y técnicas en ecología fluvial. Bilbao: Fundación BBVA, 2009. p. 219-242. Available from: $<$ http://www.fbbva.es/TLFU/microsites/ecologi a_fluvial/pdf/cap_11.pdf $>$. Accessed in: Feb. 08, 2016.

Romaní, A. M.; Guasch, H.; Balaguer, M. D. Aquatic biofilms: ecology, water quality and wastewater treatment. Girona: Caister Academic Press, 2016.

Sierra, M. V.; Gómez, N.; Marano, A. V.; Di Siervi, M. A. Caracterización funcional y estructural del biofilm epipélico en relación al aumento de la urbanización en un arroyo de la Llanura Pampeana (Argentina). Ecología Austral, v. 23, no. 2, p. 108-118, 2013. Available from: <http://www.scielo.org.ar/pdf/ ecoaus/v23n2/v23n2a04.pdf $>$. Accessed in: Feb. 08, 2016.

Sierra, M. V.; Gómez, N. Structural characteristics and oxygen consumption of the epipelic biofilm in three lowland streams exposed to different land uses. Water, Air, and 
Soil Pollution, v. 186, no. 1/4, p. 115-127, 2007. http://dx.doi.org/10.1007/s11270-0079469-y

Sierra, M. V.; Gómez, N. Assessing the disturbance caused by an industrial discharge using field transfer of epipelic biofilm. Science of the Total Environment, v. 408, no. 13, p. 2696-2705, 2010 . http://dx.doi.org/10.1016/j.scitotenv.2010.03.02 0

Stevenson, R. J. An introduction to algal ecology in freshwater benthic habitats. In: Stevenson, R. J.; Bothwell, M. L.; Lowe, R. L.; Thorp, J. H. (Eds.). Algal ecology: freshwater benthic ecosystems. San Diego: Academic Press, 1996. p. 3-30.

Streble, H.; Krauter, D. Atlas de los microorganismos de agua dulce: la vida en una gota de agua. Barcelona: Omega, 1987.

Strickland, J. D. H.; Parsons, T. R. A practical handbook of seawater analysis: pigment analysis. Ottawa: B. Journal of the Fisheries Research Board of Canada, 1968.

Sutherland, I. W. Biofilm exopolysaccharides: a strong and sticky framework. Microbiology, $\begin{array}{llll}\text { v. } 147, \quad \text { pt. } 1, & \text { p. } 3-9, & \end{array}$ http://dx.doi.org/10.1099/00221287-147-1-3

Tell, G.; Conforti, V. Euglenophyta pigmentadas de la Argentina. Stuttgart: Gebruder Borntraeger Verlagsbuchhandlung, 1986.
Van Dam, H.; Mertens, A.; Sinkeldam, J. A coded checklist and ecological indicator values of freshwater diatoms from The Netherlands. Netherlands of Journal of Aquatic Ecology, v. 28, no. $1, \quad$ p. 117-133, 1994. http://dx.doi.org/10.1007/BF02334251

Venter, O.; Brodeur, N. N.; Nemiroff, L.; Belland, B.; Dolinsek, I. J.; Grant, J. W. Threats to endangered species in Canada. Bioscience, v. 56, no. 11, p. 903-910, 2006. http://dx.doi.org/10.1641/0006-3568(2006) 56[903:TT

Villanueva, V. D.; Font, J.; Schwartz, T.; Romaní, A. M. Biofilm formation at warming temperature: acceleration of microbial colonization and microbial interactive effects. Biofouling, v. 27, no. 1, p. 59-71, 2011. http://dx.doi.org/10.1080/08927014.2010.53884 1

von Schiller, D.; Martí, E.; Riera, J. L.; Sabater, F. Effects of nutrients and light on periphyton biomass and nitrogen uptake in Mediterranean streams with contrasting land uses. Freshwater Biology, 52, no. 5, p. 891-906, 2007. http://dx.doi.org/10.1111/j.13652427.2007.01742.x

Winer, B. J. Statistical principles in experimental design. New York: McGraw Hill, 1971. 